July 2012

\title{
Treatment of the Mentally III in the Pre-Moral and Moral Era: A Brief Report
}

\author{
Michael A. Carron \\ Wayne State University School of Medicine \\ Hanna Saad \\ Wayne State University School of Medicine
}

Follow this and additional works at: https://jdc.jefferson.edu/jeffjpsychiatry

\section{Let us know how access to this document benefits you}

\section{Recommended Citation}

Carron, Michael A. and Saad, Hanna (2012) "Treatment of the Mentally III in the Pre-Moral and Moral Era: A Brief Report," Jefferson Journal of Psychiatry. Vol. 24 : Iss. 1 , Article 1.

DOI: https://doi.org/10.29046/JJP.024.1.001

Available at: https://jdc.jefferson.edu/jeffjpsychiatry/vol24/iss1/1

This Article is brought to you for free and open access by the Jefferson Digital Commons. The Jefferson Digital Commons is a service of Thomas Jefferson University's Center for Teaching and Learning (CTL). The Commons is a showcase for Jefferson books and journals, peer-reviewed scholarly publications, unique historical collections from the University archives, and teaching tools. The Jefferson Digital Commons allows researchers and interested readers anywhere in the world to learn about and keep up to date with Jefferson scholarship. This article has been accepted for inclusion in Jefferson Journal of Psychiatry by an authorized administrator of the Jefferson Digital Commons. For more information, please contact: JeffersonDigitalCommons@jefferson.edu. 


\title{
Treatment of the Mentally Ill in the Pre- Moral and Moral Era: A Brief Report
}

\author{
Michael A. Carron, M.D. \\ Hanna Saad MSIV \\ Wayne State University School of Medicine \\ 4201 St Antoine, 5E-UHC \\ Detroit, Michigan, 48201 \\ (Department) 313-577-0805 \\ (Fax) 313-577-8555 \\ hasaad@med.wayne.edu
}

Personal Contact Information

3639 Carol

Melvindale, Michigan, 48122

$313-213-3580$ 


\begin{abstract}
Throughout the ages, treatment of the mentally ill has evolved with distinct periods of progression, stagnation and regression. These differences in time mirrored how society understood mental illness and the mentally ill person on both a biological and interpersonal level. At various points in history, treatment of the mentally ill included cruel and inhumane acts, while at other times, consisted of compassionate and benevolent care. What follows is a brief comparison of how mental illness was conceptualized and how persons with mental illness were treated in the pre-moral and moral eras of medicine. The pre-moral era is from the end of the classical period to the middle 1700 's, while the moral era is considered to be from the middle 1700 's to the late 1800 's. This review highlights how personal, religious and scientific philosophies weigh heavily in creating a paradigm to conceptualize and treat mental illness. Keywords: Mental illness, Pre-moral era, Moral era, Asylum
\end{abstract}


Many believe the death of Galen marked the end of the classical era and the beginning of the pre-moral era. It was in the classical era that mental illness was thought to derive from organic causes and should be treated like other common problems like colds or constipation. In the pre-moral era, the churches gained influence and Christian monasteries resumed the duties physicians held in caring for the sick. Monastic monks found themselves attending to the care of those with mental illness. The monks prayed for them, touched them with relics and prepared potions for them to consume in hopes of bringing them back to their senses (1). At this time, religion was intimately entwined in the theories surrounding the etiology and treatment of mental illness. It was thought that if a mentally ill person could be led emotionally and spiritually closer to God that it was possible to cure them. It must be noted that during this period not all of the mentally ill were cared for in monasteries, in fact, many were cared for by their families or by local officials from their villages. Sadly, there were those who were unfortunate enough to be without family or who's problems were too difficult to care for, and they were cast from their homes and villages and forced to roam the countryside. Symonds tells us "Marginal lands outside the cities, were, therefore, populated by vagabonds, lepers, madmen and other unfortunate people. They roamed the countryside, becoming more and more bedraggled 
and losing more and more of their faculties" (2).

This was the status quo until the thirteenth century, an era in which people were faced with the harsh cruelties of plague, social unrest, famine and infectious epidemics. Ideology at this time implicated evil spirits and demons as the responsible agents for the world's ills including mental illness. Those who were delusional and hallucinating were considered to be witches in partnership with the devil. Brigham states that, "It was an ignorance of the nature of insanity, that those afflicted were not diseased, but were evil, wicked and in league with the devil, which gave way for their horrendous and barbaric treatment". Furthermore, he states that, "Between the fourteenth and eighteenth centuries thousands of mentally ill people were put to death, imprisoned for life, and burned at the stake as sorcerers and witches"(3). Hence it was the philosophy of the time that dictated the presumed etiology and subsequent treatment of mental illness. Interestingly, not all of the mentally ill were treated in the same manner. Those who were happy, sociable and brave were treated with respect and dignity, even sometimes worshiped as oracles. However, those who were quiet, depressed and unhappy were driven from the towns and villages as outcasts and were subjected to the greatest abuses (3). Essentially, the first asylums were homes, local jails or almshouses. Those kept at home were usually locked in 
a room, or, if too difficult to control or were prone to violence, would be confined to jail. There was a large number of mentally ill who were not considered threatening or prone to violence. However, many were essentially paupers without families to care for them and were kept in almshouses or taken in by the Church (4). The general consensus is that the earliest asylums housed a mix of people including beggars, handicapped and the mentally ill.

By the mid-thirteenth century, the need for hospitals for the mentally ill became apparent. One of the first and the most famous of these was the Priory of St. Mary of Bethlehem otherwise known as Bedlam. It was founded in 1243, and by 1403, it housed six mentally ill men. In 1547, Henry VIII delivered it to the jurisdiction of the city of London, where it was used solely for the purpose of containing the mentally ill. This hospital became one of the most famous tourist attractions, rivaling the Westminster Abbey and the Tower of London (5).

Until the beginning of fifteenth century, there were essentially no widespread treatments available for the care of the mentally ill. In fact, it was not until the leprosy epidemics of the fourteenth and fifteenth century began to recede, that there was even a consideration of dedicating hospital resources towards the treatment and management of the mentally ill. Once, 
the leprosy epidemic began to recede, the thousands of leprosy hospitals across Europe were converted into the first lunatic asylums (1). Now, there were specific locations dedicated toward the study, treatment and management of the mentally ill.

With the beginning of the Age of Enlightenment in the sixteenth century, scientific and medical doctrine was becoming more sophisticated and less credence was given to the supernatural as a cause of mental illness. The mentally ill were regarded less as being possessed, evil or practicing as witches, but suffering from some mysterious disease process. Unfortunately, abuse and inhumane treatment continued as many were locked away in small, filthy rooms and dungeons where they were whipped, beaten and chained to the walls and floors if they were not cooperative (3). Bedlam was one of the most notorious in the land for subjecting the "patients" to some of the most horrifying means of treatment. Brigham summarized the conditions found in Bedlam and other asylums modeled after it, "They were confined in badly ventilated apartments where they were never discharged but by death. The quiet, the noisy and the violent were all congregated together, and a majority were chained to beds by their wrists and ankles. No contemplation of human misery ever affected us so much: the howlings, execrations and clanking of chains gave to the place the appearance of the infernal 
regions"(3). This type of treatment continued on for centuries.

The eighteenth and nineteenth centuries represented the beginning of modern psychiatry and heralded the dawn of the moral era. During this time, treatment involved removing the mentally ill from the general population and assembling them into a group to be managed on a medical basis in hospitals and under the organized supervision of physicians. This is illustrated in the 1845 Lunacy Act in Great Britain, which is described as a triumphant achievement that changed the response to the mentally ill (2). However, Davison reminds us that, "It should not be assumed that the inclusion of abnormal behavior within the domain of hospitals and medicine necessarily led to more humane and moral treatment. Medical treatments were often crude and painful" (1). For example, Benjamin Rush, who is considered the father of American modern psychiatry, believed ardently that mental illness was due to an excess of blood in the brain. Because of this philosophy, his favorite treatment was to, "draw from the insane great quantities of blood". Another treatment was to frighten the patient by practically drowning them and then trying to revive them before they died (1). As Clouette tells us, "Procedures that allowed for bleeding, vomiting and purging were employed to treat the mentally ill in the hope of restoring balance to the bodily systems. This was of course an approach based on the 
concept of the balance of the four humors" (6).

This was the status quo, until August of 1793, when Frenchman Philippe Pinel removed the shackles and chains from patients in a Parisian "madhouse" known as the Menagerie. Pinel's philosophy was revolutionary because of his idea that persons with mental illness should be treated as individuals suffering from a disease, which had a differential diagnosis, prognosis and therapy. Pinel's approach to the diagnosis and treatment were truly unique because they embraced the healing values of fresh air, exercise, civilized interaction and conversation with the other patients. He was one of the first to strongly advocate that affectionate and supportive care, which mirrored that found in a family setting, would provide an optimal therapeutic environment (7). Most medical historians credit Philippe Pinel with defining and implementing the concept of moral treatment of the mentally ill. The cornerstone of this philosophy was that the mentally ill were suffering from an illness out of their control and should be approached with compassion and understanding, and treated with dignity as individual human beings (1). This idea would prove to be the catalyst, which hastened the development of other institutions, which further developed and applied a moral treatment modality.

Following Pinel's revolutionary work in France, William Tuke, a 
wealthy Quaker, was upset at the "egregious violations of standards of human decency in the treatment of the insane". In 1790, he and others established a hospital called the York Retreat where the mentally ill would be treated with Christian charity, humanity and kindness (8). To illustrate how the "rules had changed" with the practice of moral treatment, superintendent Eli Todd told his staff that, "No one will ever be allowed to confine a patient without an order from a physician or keeper. And on no occasion to use opprobrious, or even passionate language, in the discharge of his duty. Striking, beating, or in anyway maltreating the patients is made an unpardonable offense" (8)

The overall treatment philosophy of the moral era was to create a quiet and religious atmosphere where the patients could live, work and rest in comfort. Davison points out that patients were in close contact with their attendants who were responsible for reading to them, speaking with them and assisting them in engaging in normal and purposeful activity (1). The goal was that, "If in the short term, a lunatic could be cured and become able bodied again, this was a better alternative than providing custodial care for a lifetime" (2). Medications were still considered an important treatment modality and records from the original York Retreat reveal pharmacologic agents were ever present in the therapeutic regimen. Of these, alcohol, 
cannabis, opium and chloral hydrates were the most popular. These records also show that the patient outcomes were not significantly favorable and that less than one third of all the patients were discharged as improved or recovered (5).

Few would argue that a benevolent philosophy of care and the construction of "moral" institutions did not represent an enormous improvement in the care of the mentally ill. However, the original founders of moral medicine did not really understand the cause of mental illness, therefore, their treatments we quite empiric. Many would say that it was their kind natures, not a true comprehension of the nature of mental illness that motivated them to abandon the treatments of the pre-moral era and implement more compassionate care. In the moral era, the thinking was that the mentally ill could be rehabilitated by having the patient gain an acceptance of social morality, an adoption of self government within a social community, self-restraint during religious services and a desire to work. However, this philosophy was abandoned in the latter part of the nineteenth century as the moral era yielded to a medically based paradigm of treatment of the mentally ill. This transition is what ultimately gave way to the era of the modern asylum, which lasted until the 1950's (8). 
Clearly, the treatment of mental illness has varied with the philosophies of the ages. It would be difficult to deny that when compared to the pre-moral era, the moral era allowed for more humane treatment of the mentally ill. Many would hold that this was due to an increased understanding of the true nature of mental illness coupled with a strong sense of moral obligation to care for the less fortunate in society. Others would say that compassion has always existed throughout the ages and that the difference in the moral era was attributed to improved understanding into the pathophysiology if mental illness. Brigham states, "Benevolence has ever existed in the heart of man, and compassion for suffering, been manifested from the most remote period"(3). He believes that the poor treatment of the mentally ill in the pre-moral era was mainly due to the lack of insight into the origins of mental illness and not entirely due to a lack of compassion. However, the best intentions may not be successful if they are misguided--as was evident with Moral era. Those caring for the mentally ill in the moral era lacked a true understanding of the nature of mental illness and even though patients were treated with decency and compassion they were still not cured of their disease. Brigham states, “ But without knowledge, benevolence may prove to be as injurious as tyranny itself". In the end, we must diligently work to demystify the pathophysiology of 
mental illness. Ignorance has been the worst of all diseases, especially regarding the treatment of mental illness. It is only through the gain in knowledge that our treatment measures will become all the more humane and successful. 


\section{References}

1. Davison, G. Neal, J., Abnormal Psychology. New York, John Wiley and Sons. 1997.

2. Symonds, B. The origins of the insane asylums in England during the 19th century: a brief sociological review. Journal of Advanced Nursing 1995; 22:94-100.

3. Brigham, A. The Moral Treatment of Insanity. American Journal of Psychiatry 1994; 151:11-15.

4. Thompson, J. Trends in the Development of Psychiatric Services, 1844-1994. Hospital and Community Psychiatry 1994; 45:987-91.

5. McMillan, I. Insight into Bedlam: One Hospital's History. Journal of Psychosocial Nursing 1997; $35: 28-31$.

6. Clouette, B. DesLandes, P., The Hartford Retreat for the Insane: An Early Example of the Use of Moral Treatment in America. Connecticut Medicine 1997; 61:521-527.

7. Bendiner, H. Philippe Pinel: reason for the unreasoning. Hospital Practice 1981; 16:76E-76P.

8. Digby, A. The Channging Profile of a Nineteenth-Century Asylum: The York Retreat. Psychological Medicine 1984; 14:739-48. 